\title{
Reconstruction of the Psychological Characteristics of the Personality of the Writer Vladimir Nabokov
}

\author{
Marina N. Aksenovskaya \\ Counseling and Training Center, Saratov, Russia \\ Email: marina.aks2010@yandex.ru \\ Received February 2014
}

\begin{abstract}
The experience of psychological characteristics reconstruction of the personality of the writer Vladimir Nabokov is outlined in this paper by using the method of content analysis of his literary works. The main existential units included into the notional semantics of the writer's consciousness i.e. world, time, fate, life, death, memory are determined. The conclusion is drawn that post-modern perception of the reality, accompanied by depression symptoms, is typical for the writer.
\end{abstract}

Keywords

Personality, Products of Activities, Content Analysis, Meaning, Notional Semantics

\section{Introduction}

Currently, there are relatively few psychological studies devoted to the research of the certain historical figure. Probably, this is due to the fact that the character of each person is unique and standard methods of its examination are not sufficient. G. Allport, who believed that a personality is never "common" and it is always "individual” [1], attached great importance to the psychological investigations of the specific personalities. In Russian psychology the psychological surveys of the individual historical personalities are conducted by E.U. Korzhova [2], V. A. Koltsova, E. N. Holondovich [3]. Some psychologists consider it right to use literary texts as a material for psychological investigation of the personality being (E. U. Korzhova, B. M. Teplov, F. E. Vasiluk, etc.).

Analysis of the author's activity products appears to be sufficient enough for his profile recreation and psychobiography writing. H.-G. Gadamer wrote in his work "Truth and Method" [4] that the author's actual being should be searched in his creative works, in the depth of his imaginable system always demanding interpretation.

In D. A. Leontiev's opinion, the content put into the work of art by the artist appears to be the answers for the questions directed to him by life. "The sense that the art work brings is the answer to a life 'problem on sense' facing an artist or the pointed intended statement of this problem [5]."

The writer's creative work products investigation produces the access to the content of his inner world, per- 
sonal meanings system, psychological semantics, perception; makes it possible to find out the originality and unique character of his personality, and to get an idea about the personal world view, personality type, neurotic disorder extent, manners of response to reality situations through the study of the personal meanings system.

The purpose of this article is to present the basic results of the reconstruction of the writer Vladimir Nabokov's psychological characteristics.

\section{The Main Results of the Psycho-Semantic Investigation of Vladimir Nabokov's Creative Activity Products}

Research method. The research method is the content-analysis of Vladimir Nabokov's novels.

Empirical base of the study. The empirical base of the study were four novels by Vladimir Nabokov ("The Luzhin Defence”, “The Real Life of Sebastian Knight”, “Speak, Memory”, “Look at the Harlequins!”) [6]-[9].

\section{Results and Discussion}

After content-analysis of the Nabokov's novels we can draw the conclusion that the content of the writer's personal meanings system is objectified in his creative activity products.

The following semantic units: world (being), time, fate, life, death, memory were the main value center in the individual perception of Vladimir Nabokov detected using the content analysis. The other semantic categories such as creativity, a gift, an artist, etc., which were not the subject for study were also very important.

The inner conflicts natural for the author were expressed in his creative work. The analysis of the creative work products reflected the essential content of the personal meanings system of the perception of Vladimir Nabokov's personality.

Due to the content-analysis of Vladimir Nabokov's creative work products and personal meanings system diagnosis of his perception it may be deduced that the personality of Vladimir Nabokov appears to be the bearer of the crisis consciousness. The crisis consciousness was developed as a result of the life crisis that happened in Nabokov's course of life. The "worldview" which had existed in Nabokov's consciousness before 1917 was ruined. The external world didn't lend itself to any manipulations from his part any more. The deep world outlook crisis took place ("the destruction of the concepts of the past", of the world order) as well as different identity crises such as crises of the identities (social, ethnical, civil, family). However, new concepts of the world never formed the single harmonious system. Henceforward there was a "chaotic idea of the world" in the writer's perception. Vladimir Nabokov could gain the sense of stability only in the 1960s of the twentieth century (but he was not very likely to find the psychological feeling of the harmonious worldview).

As a part of the study of Vladimir Nabokov's novels the following main semantic categories important for the writer's mentality: world, time, fate, memory, life and death were revealed.

1) World. The world of the writer is broken into two parts: his own - “inner", friendly and strange- "external”, hostile. The painful feeling of apartness from others is the writer's way.

2) Time. The writer is constantly retrospective. The time is outlined with the short line of the future. His future is merged in the past and the present.

3) Fate. A personified image like the Classical Greek goddess that designs his fate and controls life and death of a man.

4) Memory. The writer swears by autobiographical memory. The obtrusive reflection of the past facts, writing of the autobiographies is his nature and that is indicative of a tendency to summing-ups.

5) Life and death. Life is perceived as an instant absorbed by death.

The semantic categories found out as a result of the study of the four Nabokov's novels bear the imprint of critical consciousness and enable to diagnose the symptoms of light depression. The creative work in Vladimir Nabokov's life besides the self-updated function performs therapeutic one and helps to bear with the rapidly changing life conditions (life in emigration, the course of life crises and difficulties) as well as to form new behavioral patterns in new conditions of life. The writing identity chosen in his teen-age (Nabokov aimed to be a writer when he was 16 years old) serves as an adaptive function to rapidly changing living conditions in the world that doesn't accept him for some time past (isolated existence in the emigrant environment, impossibility of step out of emigrant Diaspora). The former identities - the wealthy aristocrat, the Empire citizen — vanished and only the writing identity remained as some starting point being in contact with the past and from which it is possible to form a new line (other identities), adapting himself to the henceforth unfriendly world. As a result, 
the personality of Vladimir Nabokov became the bearer of the "crisis perception" typical for the postmodern world view.

"Identification crisis" also appears to be in the consciousness of the writer's personality. Therefore, there is the constant appealing to the autobiographical memory as to the certain starting point from which the writer forms his new identities. The personal philosophy of V. Nabokov reflects in his creative work products. Postmodernism appears to be a characteristic of the certain mentality, specific manner of world perception, attitudes and valuation both perceptive human capabilities and his place and role in the world around. Postmodern literature is characterized by the specific structure of the literary text reflecting the special worldview constellation. The basic principles and notions of the postmodern texts structure are the following: "the world as a chaos", postmodern sensitivity, "the world as a text" and "the consciousness as a text", intertextuality, "crisis of authorities”, epistemological uncertainly, author's mask, dual code, parodical mode of narration, pastiche, contradictory, discretion, fragmentary nature of the narration (nonselection principle), etc. While analyzing Nabokov's texts all the above mentioned elements are in evidence. For Nabokov's narrative manner the ironical narration is appropriate. His texts are full of inter-texts, language notional and stylistic games, contradictory and multiplicity of narration, significance of texts interpretation.

In his literary texts Vladimir Nabokov appears to be a theoretician of his own creative work. The writer's texts are overflown with thoughts about art work nature, writing style, creative work and creative skill. This gives evidence of great absorption into his own inner world where the writer reconstructs capacity for reality control.

\section{Conclusion}

The internal element of the personality is objectified in the consciousness. The access to this information is possible by means of personal meanings system study, interpretations of the notional semantics of the literary work author. Creative personality activity products objectify personal meanings important for the personality in the indirect artistic form and enable to express mentality and attitudes to reality more frankly (both consciously and unconsciously), not being afraid of critical eye of the opponents.

The psychological testing of the activity products using method of the content analysis produce additional data about the personality under test and contribute to the recreation of the holistic vision of this personality.

The performed reconstruction of the psychological characteristics of the writer Nabokov's personality was aimed at the determination of the main elements of his notional semantics and their connection with the crisis situations of the writer's biography reflected in his creative work. Among the main semantic elements there is world, time, fate, memory, life and death. The writer's personality is the bearer of the crisis consciousness implemented in the postmodern style of his creative work.

\section{References}

[1] Allport, G. (2002) Achievement of Personhood, Moscow, Smisl, 462. Олпорт Г. Становление личности. М.: Смысл. 2002, 462 c.

[2] Korzhova, E.U. (2009) The Psychology of Personality in Novelry. In: Newsletter of Gertzen RSPU №100, 77-87. Коржова Е.Ю.Психология личности в художественной литературе. //Известия РГТУ им. А.И. Герцена. 2009. № 100. C. 77-87.

[3] Koltzova, V.A. and Holondovich, E.N. (2013) Personification of Inwardness in Personality and Creative Work of Dostoyevsky. Moscow, Institute of Psychology RAS, 304. Кольцова В.А., Холондович Е.Н. Воплощение духовности в личности и творчестве Достоевского. М.: Институт психологии РАН, 2013. 304c.

[4] Gadamer, H.-G. (1988) Truth and Method. The Basics of the Philosophical Hermeneutics. Moscow. Progress, 704. Гадамер Х.-Г. Истина и метод: Основы филос. Герменевтики. М.: Прогресс, 19886704 с.

[5] Leontiev, D.A. (2003) Psychology of the Sense. Nature, Structure and Dynamics of Conceptual Reality. Moscow, Smysl, 445. Леонтьев Д. А. Психология смысла. Природа, строение и динамика смысловой реальности. М.: Смысл, 2003. 445 с.

[6] Nabokov, V.V. (1990) The Luzhin Defence. Collected Edition in 4 Volumes, Volume 2, Moscow, Pravda, 5-155. Набоков В.В. Защита Лужина. Собр. Соч. в 4-х т. Т.ІІ. М. Изд-во Правда, 1990. С. 5-155.

[7] Nabokov, V.V. (1993) The Real Life of Sebastian Knight. Bend Sinister: Novels, St. Petersburg, North-West, 6-157. Набоков В.В. “Истинная жизнь Себатьяна Найта”. Bend Sinister: Романы. СПб.: Северо-Запад, 1993. 527 с. С. 
6-157.

[8] Nabokov, V.V. (1999) Spear, Memory. Autobiography. Reconstruction of S. Iljin. American Period. Collected Edition in 5 Volumes: Translation from English, Ed. S. Iljina, A. Kononov, St. Petersburg, Symposium, 314-597. Набоков B.B. Память, говори. Автобиография. Реконструкция С. Ильина. Американский период. Собрание сочинений в 5 томах: Пер. с англ. Сост. С. Ильина, А. Кононов. СПб.: Симпозиум, 1999. 314-597.

[9] Nabokov, V.V. (1999) Look at the Harlequins! Translation from English. American Period. Collected Edition in 5 Volumes. Ed. S. Iljina, A. Kononov, St. Petersburg, Symposium, 98-314. Набоков В.В. Смотри на арлекинов. Пер. с англ. Американский период. Собрание сочинений в 5 томах: Пер. с англ. Сост. С. Ильина, А. Кононов. СПб.: Симпозиум, 1999. С. 98-314. 